\title{
PEMATAHAN DORMANSI BENIH PALA (Myristica fragrans Houtt.) MENGGUNAKAN HORMON GIBERALIN
}

\author{
Lisa Agurahe $^{1)}$, Henny L. Rampe ${ }^{1)}$, Feky R. Mantiri ${ }^{1)}$ \\ 1) Jurusan Biologi FMIPA UNSRAT Manado, 95115 \\ Email:_Hennyrampe@unsrat.ac.id; lisaaguraeh12@gmail.com ; fmantiri@yahoo.com
}

\begin{abstract}
This study aims to determine the breakdown of nutmeg seed dormancy after application using the hormone giberalin, and get the best concentration of giberalin in breaking nutmeg seed dormancy. This research was conducted at the Laboratory of Basic Biology, Biology Study Program, Faculty of Mathematics and Natural Sciences, Sam Ratulangi University in December 2017 to February of 2018. This study used the experimental method Complete Random Design (CRD) with three replications. Treatment of Giberalin hormone concentration with four levels of treatment, namely GA3 0 ppm (G0) (control), GA3 25 ppm (G1), GA3 50 ppm (G2), and GA3 75 ppm (G3). The parameters observed were germination potential, germination similarity, vigor index and vigor coefficient. The results showed that the application of the giberalin hormone had a significant effect on the viability of nutmeg seeds including the potential for germination (Sig =0,00) and the similarity of germination in the 27th day study of G1 and G2 treatment of $11.11 \%$. The potential results of germination on nutmeg seed reached $100 \%$ at 54 HST. Observation of seed vigor obtained by the value of vigor index is 12.37 and the vigor coefficient is 14.400
\end{abstract}

Keywords: Nutmeg seeds, Giberalin, Vigor, Viability

\begin{abstract}
ABSTRAK
Penelitian ini bertujuan mengetahui pematahan dormansi benih pala setelah aplikasi menggunakan hormon giberalin, dan mendapatkan konsentrasi giberalin yang paling baik dalam mematahkan dormansi benih pala. Penelitian ini di Laboratorium Biologi Dasar Program Studi Biologi, Fakultas Matematika Dan Ilmu Pengetahuan Alam, Universitas Sam Ratulangi pada bulan Desember Tahun 2017 sampai Februari Tahun 2018. Penelitian ini menggunakan metode eksperimen Rancangan Acak Lengkap (RAL) dengan tiga kali ulangan. Perlakuan konsentrasi hormon Giberalin dengan empat taraf perlakuan yaitu $\mathrm{GA}_{3} 0$ ppm (G0) (kontrol), GA 25 ppm (G1), GA 50 ppm (G2), dan $\mathrm{GA}_{3} 75 \mathrm{ppm}$ (G3). Parameter yang diamati adalah potensial berkecambah, keserempakan perkecambahan, indeks vigor dan koefisien vigor. Hasil penelitian menunjukkan aplikasi hormon giberalin berpengaruh nyata terhadap viabilitas benih pala meliputi potensial berkecambah (Sig= 0,00) dan keserempakan perkecambahan pada penelitian hari ke 27 perlakuan G1 dan G2 yaitu $11,11 \%$. Hasil pengamatan potensial berkecambah pada benih pala mencapai $100 \%$ pada 54 HST. Pengamatan vigor benih diperoleh nilai indeks vigor yaitu 12,37 dan koefisien vigor yaitu 14.400.
\end{abstract}

Kata kunci: Benih Pala, Giberalin, Vigor, Viabilitas 


\section{PENDAHULUAN}

Tanaman pala (Myristica fragrans Houtt) merupakan tanaman asli Indonesia dan sebagai salah satu komoditas ekspor penting, karena sekitar $70 \%$ kebutuhan pala dunia dipasok dari Indonesia. Buah pala dikenal sebagai tanaman rempah yang memiliki nilai ekonomis dan multiguna. Setiap bagian tanaman, mulai dari dagin buah, biji, hingga tempurung pala dapat dimanfaatkan untuk industri makanan, minuman, maupun kosmetik. Tanaman pala dapat dikembangkan secara vegetatif dan generatif (Rismunandar, 1990).

Biji pala memiliki tempurung keras sehingga menyebabkan resistensi dan terhambatnya perkecambahan biji. Kondisi seperti ini disebut dormansi mekanis, sehingga untuk berkecambah memerlukan waktu 4-8 minggu. Salah satu upaya mempercepat perkecambahan biji pala adalah memudahkan masuknya air dan udara ke embrio dengan merusak impermeabilitas kulit biji, dengan cara memberi perlakuan mekanis dan kimia pada biji (Putu et al., 2015).

Biji pala termasuk jenis biji rekalsitran yaitu biji yang cepat rusak dan viabilitas menurun apabila diturunkan kadar airnya, dan tidak tahan disimpan pada suhu dan kelembaban rendah, serta waktu perkecambahannya lama (Yuniarti dan Rustam 2011 dalam Erydhatirti, 2014).

Penyebab dari adanya lambat perkecambahan adalah tebalnya kulit biji, ketidakseimbangan senyawa perangsang, dan penghambat untuk memacu aktivitas perkecambahan biji. Hal ini menyebabkan perkecambahan biji menjadi sangat lambat atau mengalami dormansi. Biji pala memiliki masa dormansi yang cukup panjang disebabkan oleh keadaan fisik dari kulit biji (Muhammad et al., 2008).

Dormansi adalah keadaan
pertumbuhan dan metabolisme yang terpendam, dapat disebabkan oleh kondisi lingkungan yang tidak baik atau faktor dari tumbuhan itu sendiri. Dormansi juga merupakan suatu prinsip kerja dari biji tanaman untuk mempertahankan diri terhadap suhu yang sangat rendah pada musim dingin, bahkan pada suhu yang lebih panas (Sasmitamihardja dan Siregar, 1997).

Beberapa perlakuan dapat diberikan pada biji, sehingga tingkat dormansinya dapat diturunkan dan presentase kecambahnya tetap tinggi. Perlakuan tersebut dapat ditujukan pada kulit biji, embrio, maupun endosperm biji. Hal ini dimaksudkan untuk menghilangkan faktor penghambat perkecambahan dan mengaktifkan kembali sel-sel yang dorman. Dormansi biji dapat dibedakan atas beberapa tipe dan kadang-kadang satu jenis biji memiliki lebih dari satu tipe dormansi. Dormansi biji berpengaruh terhadap viabilititas dan vigor biji. Dormansi biji dapat dipatahkan dengan cara: 1) perlakuan mekanis seperti skarifikasi dan tekanan; 2) perlakuan dengan perendaman air; 3) perlakuan dengan cahaya; dan 4) perlakuan kimia (William, 2014 dalam Naning, 2015).

Pematahan dormansi dengan bahan kimia dapat digunakan kalium hidroksida, asam hidroklorit, kalium nitrat, thiourea, dan giberalin.

Giberalin merupakan hormon yang mempercepat perkecambahan biji, kuncup tunas, pemanjangan batang, pertumbuhan daun, merangsang pembungaan, perkembangan buah, mempengaruhi pertumbuhan, dan diferensiasi akar. Giberalin merupakan hormon tumbuh pada 
tanaman yang bersifat sintesis dan berperan mempercepat perkecambahan. Penelitian yang dilakukan oleh Murniati dan Zuhri (2002), mendapatkan bahwa giberalin mampu mempercepat perkecambahan biji kopi dengan konsentrasi rata-rata perkecambahan dan laju perkecambahan tertinggi pada konsentrasi 80 ppm (Bey et al., 2005 dalam Ratna et al., 2013).

Penelitian Nurshanti (2009) pada biji palem raja dengan menggunakan hormon giberalin dengan kosentrasi 75 ppm diperoleh persentase kecambah hidup yang lebih tinggi yakni 32\% dibanding perlakuan konsentrasi lainnya. Selanjutnya pengujian perkecambahan dengan hormon giberalin oleh Dina. (2012) mendapatkan bahwa pemberian giberalin $300 \mathrm{ppm}$ memberikan hasil terbaik terhadap daya perkecambahan, bobot basah dan kering tajuk pada perkecambahan biji pinang (Areca catechu). Pengaruh fisiologi giberalin pada perkecambahan biji yaitu mendorong pemanjangan sel sehingga radikula dapat menembus kulit biji, dimana giberalin mendorong aktifitas enzim-enzim hidrolitik dalam proses perkecambahan.

Menurut Purnobasuki (2011), perkecambahan adalah peristiwa tumbuhnya embrio di dalam biji menjadi tanaman baru. Perkecambahan dapat dilihat dari vigor dan viabilitas biji. Vigor merupakan kemampuan biji untuk tumbuh normal pada keadaan lingkungan yang suboptimal (Sutopo, 1993). Biji yang bervigor tinggi akan dapat mencapai tingkat produksi yang tinggi, yang dicirikan antara lain tahan disimpan lama, cepat tumbuhnya, dan mampu menghasilkan tanaman dewasa yang normal. Pematahan dormansi biji dapat diukur dari parameter viabilitas dan vigor (Zahrotun et al., 2017)
Sadjad (1975) dalam Oben et al., (2014), menyatakan bahwa viabilitas biji adalah daya hidup biji untuk tumbuh menjadi kecambah. Tolak ukur parameter viabilitas biji yaitu daya kecambah. Viabilitas dikelompokkan menjadi viabilitas potensial yaitu kemampuan biji untuk hidup dan viabilitas total yaitu kemampuan biji untuk berkecambah dan tumbuh normal pada kondisi optimum, untuk menjadi tanaman normal, dan berproduksi. Vigor biji adalah kemampuan biji menghasilkan tanaman normal pada lingkungan yang kurang memadai (sub-optimum) dan mampu disimpan pada kondisi yang suboptimum (Sadjad, 1993).

Berdasarkan uraian di atas dan ditinjau dari segi morfologi biji pala yang dilindungi oleh tempurung yang keras, serta memiliki masa dormansi yang cukup panjang yaitu memerlukan waktu dua bulan untuk berkecambah (Arijani, 2005), maka dilakukan penelitian pematahan dormansi biji pala dengan menggunakan hormon giberalin.

Penelitian ini bertujuan untuk mengetahui pematahan dormansi benih pala (Myristica fragrans) setelah aplikasi menggunakan hormon giberalin dan mendapatkan konsentrasi hormon giberalin yang paling baik dalam mematahkan dormansi benih pala (Myristica fragrans).

\section{METODE PENELITIAN}

\section{Waktu dan Tempat}

Penelitian ini dilaksanakan pada bulan Desember Tahun 2017 sampai bulan April Tahun 2018 bertempat pada Laboratorium Biologi Dasar Program Studi Biologi, Fakultas Matematika dan Ilmu Pengetahuan Alam, Universitas Sam Ratulangi, Manado. 


\section{Alat dan Bahan}

Alat yang digunakan dalam penelitian ini adalah: oven, timbangan analitik, gelas ukur, gelas kimia, pipet, konteiner plastik ukuran $38 \times 30 \times 15 \mathrm{~cm}$, sarung tangan, kertas label, kertas tissue, kamera dan alat tulis. Bahan yang digunakan meliputi: biji pala matang fisiologi, akuades, hormone Giberalin, dan media tanam tanah bercampur pasir.

\section{Rancangan Penelitian}

Penelitian ini menggunakan metode eksperimen Rancangan Acak Lengkap dengan tiga kali penggulangan. Perlakuan hormon giberalin (GA) yang diberikan yaitu konsentrasi GA 0 ppm kontrol $\left(\mathrm{G}_{0}\right)$, GA 25 ppm $\left(\mathrm{G}_{1}\right)$, GA 50 ppm $\mathrm{G}_{2}$, dan GA 75 ppm $\left(\mathrm{G}_{3}\right)$.

\section{Prosedur Penelitian}

1. Persiapan sampel

Biji berasal dari buah yang telah masak penuh (matang fisiologi) diambil dari perkebunan warga di Desa Tombuluan, Kabupaten Minahasa, Provinsi Sulawesi Utara. Buah pala dipisahkan dari bijinya kemudian dibersihkan dari fuli dan dicuci bersih.

Media tanam yang digunakan yaitu tanah bercampur pasir dengan perbandingan 1:1. Metode ini dirujuk dari penelitian yang dilakukan oleh Yuniarti et al. (2015). Pasir dapat digunakan untuk menurunkan tingkat kekerasan tanah sehingga akar lebih mudah menembus tanah. (Hakim et al., 1986 dalam Bukhari, 2013).

2. Pembuatan larutan giberalin

Pembuatan larutan GA dengan konsentrasi 25, 50, dan 75 ppm, untuk membuat larutan GA 25 ppm yaitu $25 \mathrm{mg}$ GA dilarutkan dalam $1 \mathrm{~L}$ aquades, untuk larutan GA 50 ppm yaitu $50 \mathrm{mg}$ GA dilarutkan dalam $1 \mathrm{~L}$ aquades, dan untuk 75 ppm yaitu melarutkan 75 mg GA di larutkan dalam $1 \mathrm{~L}$ aquades.

3. Pemilihan, Kadar air dan Daya imbibisi

Pemilihan benih pala yang digunakan dalam penelitian yaitu dengan cara merendam biji pala yang telah dibersihkan dalam air.

Biji pala yang tenggelam dipilih sebagai bahan penelitian yang selanjutnya disebut benih. Benih pala kemudian dikeringkan pada suhu ruangan selama 90 menit dan ditimbang untuk mendapatkan sampel homogen. Berat sampel benih pala yang digunakan dalam penelitian yaitu 8,00 $-9,00 \mathrm{~g}$.

Pengukuran kadar air dilakukan dengan cara diambil 10 benih secara acak dan dihitung kadar airnya menggunakan metode oven selama 4 jam pada suhu $105^{\circ} \mathrm{C}$. Suhu ini digunakan untuk benih yang mengandung minyak-minyak atsiri (Sutopo, 1993). Pengukuran daya imbibisi dengan cara, diambil secara acak 10 benih kemudian ditimbang dan direndam dalam konteiner plastik yang berisi akuades selama dua jam selanjutnya ditimbang kembali. Metode ini dirujuk dari penelitian yang dilakukan oleh Handayani (2017). Pengukuran daya imbibisi bertujuan untuk mengetahui daya serap atau kemampuan benih untuk menyerap.

\section{Perlakuan}

Benih pala direndam dalam hormon giberalin sesuai perlakuan selama tiga jam. Selanjutnya benih pala diangkat, ditiriskan kemudian ditanam dengan posisi embrio benih menyentuh media tanam

5. Pemeliharaan dan Pengamatan

Pemeliharaan berupa penyiraman air dengan volume sama sebanyak $50 \mathrm{ml}$ untuk 
tiap benih pada semua perlakuan dan dilakukan sekali sehari. Metode ini dirujuk dari penelitian oleh Mokodompit (2005). Pengamatan dilakukan setiap hari dengan mencatat setiap biji yang mulai berkecambah, dimana kriteria kecambah diawali dengan munculnya radikula dan plumula.

\section{Parameter yang Diukur}

1.Viabilitas Biji

Viabilitas biji dapat diukur dengan parameter yang dikelompokkan menurut ISTA dalam Lesilolo et.al., (2013) sebagai berikut:

a. Potensi Berkecambah

$$
P B=\frac{\text { Jumlah kecambah hidup }}{\text { Jumlah biji }}
$$

b. Keserempakan Perkecambahan (KP)

$$
\mathrm{KP}=\frac{\begin{array}{c}
\text { Jumlah kecambah hidup } \\
\text { pada tengah waktu } \\
\text { perkecambahan }
\end{array}}{\begin{array}{c}
\text { Jumlah biji yang } \\
\text { dikecambahkan }
\end{array}} \mathrm{X} 100
$$

\section{Vigor Biji}

Kecepatan berkecambah yang dilihat dari vigornya, dapat dihitung menggunakan rumus menurut Nengsih. (2017)) sebagai berikut:

a. Indeks Vigor

$$
\text { Indeks Vigor }=\frac{G_{1}}{D_{1}}+\frac{G_{2}}{D_{2}}+\ldots \ldots \frac{G_{n}}{D_{n}}
$$

b. Koefisien Vigor

Koefisien Vigor

$$
=100\left(G_{1} D_{1}+\cdots G_{n} D_{n}\right)
$$

Dimana: G: Jumlah kecambah pada hari tertentu

D: Waktu yang berkoresponden dengan jumlah kecambah tersebut.

\section{Analisis Data}

Data yang diperoleh dari hasil penelitian kemudian dianalisis dengan menggunakan Analisis Varian (ANAVA) dan jika signifikan dilanjutkan dengan uji BNT taraf 0,05.

\section{HASIL DAN PEMBAHASAN}

Perkecambahan merupakan proses awal pertumbuhan individu baru pada tanaman yang diawali dengan munculnya radikula dan plumula. Perkecambahan sangat dipengaruhi oleh ketersediaan air dalam media pertumbuhan. Air akan diabsorbsi dan digunakan untuk memacu aktivitas enzim metabolisme perkecambahan (Agustrina, 2008). Dalam penelitian ini diawali dengan perhitungan kadar air dan imbibisi benih pala.

Hasil pengukuran kadar air dan imbibisi biji pala ditunjukkan pada Lampiran 1. Berdasarkan data tersebut diperoleh nilai rata-rata kadar air adalah $6,25 \%$. Hal ini menunjukan bahwa benih pala yang digunakan sebagai sampel penelitian telah memenuhi syarat sebagai benih. Sesuai dengan pendapat Sutopo (1993) yang menyatakan bahwa kadar air benih normal adalah 6-8\%. Kadar air yang tinggi dapat menyebabkan benih berkecambah sebelum ditanam sedangkan kadar air yang terlalu rendah dapat menyebabkan kerusakan pada embiro. Kadar air adalah presentasi kandungan air suatu bahan, yang sangat berpengaruh terhadap suatu benih.

Data hasil pengukuran daya imbibisi biji pala diperoleh nilai rata-rata yaitu 0,23 g. Daya imbibisi menyatakan kemampuan biji untuk menyerap air yang diperlukan dan sebagai tahap awal perkecambahan. Imbibisi menyebabkan biji mengembang dan 
Tabel 2. Analisis Varian Potensial Berkecambah Benih Pala (Myristica fragrans)

\begin{tabular}{ccc}
\hline Potensial Berkecambah & Nilai F & Sig \\
\hline 14 HST & 45,980 & $0,00 *$ \\
28 HST & 48,948 & $0,00 *$ \\
42 HST & 100,008 & $0,00 *$ \\
\hline
\end{tabular}

Ket: $*$ Sig $<0,05$

memecahkan kulit biji serta memicu perubahan metabolik pada embrio sehingga dapat melanjutkan pertumbuhannya. Enzimenzim akan menghidrolisis bahan-bahan yang disimpan dalam kotiledon dan nutriennutrien didalamnya. Enzim yang berperandalam hidrolisis cadangan makanan adalah enzim amilase, dan protease (Surya, 2010 dalam Supardy et al., 2016).

Benih sebagian besar tumbuhan biasanya berkecambah dengan segera bila diberi air, didukung dengan suhu yang memadai, cahaya matahari, dan keadaan lingkungan yang sesuai. Beberapa tumbuhan bijinya tidak segera berkecambah meskipun kondisi lingkungan yang mendukung. Benih tersebut mengalami dormansi. Peristiwa dormansi biasanya terjadi sebagai akibat dari embrio, kulit benih, dan faktor lingkungan. (Prawiranata et al., 1988).

\section{Viabilitas Biji}

\section{a. Potensial Berkecambah (PB)}

Penelitian ini menggunakan giberalin dengan konsentrasi larutan yang berbeda. Pengamatan rata-rata potensial berkecambah benih pala pada 14 HST, untuk perlakuan giberalin konsentrasi $50 \quad \operatorname{ppm} \quad\left(\mathrm{G}_{2}\right)$ menunjukkan nilai potensial berkecambah tertinggi $75 \%$. Selanjutnya diikuti perlakuan

giberalin konsentrasi 75 ppm $\left(\mathrm{G}_{3}\right)$ yaitu $42,77 \%$, perlakuan giberalin konsentrasi 25 ppm $\left(G_{1}\right)$ yaitu 5,56 ppm. Nilai potensial berkecambah terendah yaitu perlakuan giberalin 0 ppm $\left(\mathrm{G}_{0}\right)$ sebagai kontrol yaitu $0 \%$.

Pengamatan pada 28 HST, nilai potensial berkecambah tertinggi yaitu pada perlakuan $G_{2}$ dan $G_{1}$ yaitu $94,45 \%$, kemudian diikuti perlakuan $\mathrm{G}_{1}$ yaitu $61,12 \%$. Nilai potensial berkecambah terendah pada perlakuan $\mathrm{G}_{0}$ yaitu $0 \%$. Pada pengamatan 42 HST, nilai potensial berkecambah pada perlakuan $G_{2}, G_{3}$ dan $G_{1}$ telah mencapai $100 \%$, Dan nilai potensial berkecambah pada perlakuan $\mathrm{G}_{0}$ yaitu $16,67 \%$. Pengamatan terakhir pada 54 HST nilai potensial berkecambah untuk semua perlakuan telah mencapai $100 \%$.

Pada pengamatan yang terakhir 54 HST setiap perlakuan telah mencapai nilai $100 \%$. Hal ini berarti setiap benih pala dengan perlakuan hormon giberalin telah berhasil dipatahkan masa dormansi dan telah bertumbuh walaupun dalam kondisi yang suboptimum. Data pengamatan dormansi dapat dilihat pada Lampiran 3.

Menurut Abidin, (1987) dalam Asra, (2014) perendaman benih dalam larutan

Tabel 1. Rerata Potensial Berkecambah (\%) Benih Pala (Myristica fragrans)

\begin{tabular}{ccccc}
\hline \multirow{2}{*}{ Perlakuan } & \multicolumn{4}{c}{ Hari Sesudah Tanam (HST) } \\
\cline { 2 - 5 } & 14 & 28 & 42 & 54 \\
\hline $\mathrm{GA}_{3} 0 \mathrm{ppm}\left(\mathrm{G}_{0}\right)$ & $0_{\mathrm{a}}$ & $0_{\mathrm{a}}$ & $16,67_{\mathrm{a}}$ & 100 \\
\hline $\mathrm{GA}_{3} 25 \mathrm{ppm}\left(\mathrm{G}_{1}\right)$ & $5,56_{\mathrm{b}}$ & $61,12_{\mathrm{b}}$ & $100_{\mathrm{b}}$ & 100 \\
& & & & \\
\hline $\mathrm{GA}_{3} 50 \mathrm{ppm}\left(\mathrm{G}_{2}\right)$ & $75_{\mathrm{d}}$ & $94,45_{\mathrm{c}}$ & $100_{\mathrm{b}}$ & 100 \\
& & & & \\
\hline $\mathrm{GA}_{3} 75 \mathrm{ppm}\left(\mathrm{G}_{3}\right)$ & $42,77_{\mathrm{c}}$ & $94,45_{\mathrm{c}}$ & $100_{\mathrm{b}}$ & 100
\end{tabular}


giberalin dapat menyebabkan terjadinya pelunakkan kulit benih sehingga lebih permeabel terhadap air dan oksigen. Hal ini akan memudahkan benih menyerap larutan giberelin, dengan masuknya giberalin ke dalam benih akan merangsang pembentukan enzim alfa amilase untuk mengubah pati menjadi glukosa.

Abidin. (1984) dalam Mokodompit (2015), peranan giberalin dan auksin terhadap pertumbuhan tanaman yaitu meransang pemanjangan sel dan akibatnya terjadi pemanjangan batang. Tinggi tanaman akan mengalami penurunan apabila melewati konsentrasi tertentu. Hal ini dikarenakan kebutuhan hormon tumbuh bagi tanaman sangat rendah dan apabila melewati konsentrasi tertentu hormon akan menjadi inhibitor atau penghambat tumbuhan. Belakhir et al., (1998), menyatakan bahwa fungsi hormon giberalin adalah sebagai hormon tumbuh, dimana senyawa ini aktif dalam konsentrasi rendah dan bersifat merangsang, menghambat atau merubah proses fisiologi tanaman secara kuantitatif atau kualitatif.

Penelitian pengaruh pemberian hormon giberalin oleh Arifin et al., (2014) pada cabai merah keriting dengan pemberian benih lebih tinggi dibanding kontrol. Adapun pengaruh giberalin terhadap pertumbuhan vegetatif merangsang aktifitas pembelahan sel pada daerah meristem batang dan kambium, disamping itu giberalin juga merangsang pemebasaran sel sehingga mempercepat tumbuhnya batang dan daun pada tanaman.

Pengamatan pada perlakuan $\mathrm{G}_{0}$ (kontrol), perkecambahan benih pala baru berkecambah pada hari ke- 42 HST. Peristiwa ini berarti telah memenuhi teori dan waktu perkecambahan benih pala sebenarnya atau tanpa perlakuan hormon giberalin. Waktu yang dibutuhkan benih pala untuk berkecambah adalah 60 hari (dua bulan), sedangkan jika dibandingkan dengan benih pala yang diaplikasikan dengan giberalin waktu untuk berkecambah menjadi lebih singkat yaitu 14 HST.

b. Keserempakan Perkecambahan (KP)

Keserempakan perkecambahan benih pala pada 27 HST menunjukkan aplikasi GA3 tidak berpengaruh terhadap keserempakan perkecambahan dan nilai Sig=0,119 pada taraf uji 0,05 dengan Sig > 0,05 . Hal ini terjadi karena pada tiap benih pala dari perlakuan $G_{1}, G_{2}$ dan $G_{3}$ telah diberikan perlakuan hormon giberalin

Tabel 4. Hasil Analisis Varian Keserempakan Perkecambahan Biji Pala (Myristica fragrans)

\begin{tabular}{ccc}
\hline $\begin{array}{l}\text { Keserempakan } \\
\text { Perkecambahan }\end{array}$ & Nilai F & Sig. \\
\hline 27 HST & 2,667 & 0,119
\end{tabular}

Ket: $*$ Sig $<0,05$

giberalin konsentrasi 0, 20, 40, dan, 60 ppm menunjukkan bahwa konsntrasi 20 ppm dapat meningkatkan pertumbuhan daun yang lebih cepat. Penelitian Chaudhary (2006), menunjukkan pemberian hormon giberalin 30 ppm meningkatkan produksi buah jambu dengan konsentrasi yang berbeda-beda, maka waktu pertumbuhan juga berbeda tergantung konsentrasi yang diberikan. Homogenitas perkecambahan diawali dengan keserempakan perkecambahan benih 


\begin{tabular}{lcc}
\hline Perlakuan & $\begin{array}{c}\text { Banyaknya } \\
\text { Benih }\end{array}$ & $\begin{array}{c}\text { Keserempakan } \\
\text { Perkecambahan }(\%)\end{array}$ \\
\hline GA 0 ppm $\left(\mathrm{G}_{0}\right)$ & 0 & 0 \\
$\{$ kontrol $\}$ & 4 & 11,11 \\
GA 25 ppm $\left(\mathrm{G}_{1}\right)$ & & 11,11 \\
GA 50 ppm $\left(\mathrm{G}_{2}\right)$ & 4 & 0 \\
GA 75 ppm $\left(\mathrm{G}_{3}\right)$ & 0 & \\
\hline
\end{tabular}

ANGI,

ri 2019

pada kemampuannya untuk tumbuh normal pada semua kondisi lapang maupun setelah benih melampaui periode simpan lama (Sutopo, 2004).

1. Indeks Vigor

Data perhitungan indeks vigor dapat dilihat pada Lampiran 5. Berdasarkan hasil perhitungan nilai indeks vigor benih pala yaitu 12,37. Hal ini menunjukkan pada kecepatan benih berkecambah yang ditandai dengan terbentuknya plumula dan radikula.

Benih yang bervigor tinggi mampu menunjukkan kinerja yang baik dalam proses perkecambahan dalam kondisi lingkungan yang beragam (ISTA, 2007). Terdapat beberapa faktor yang mempengaruhi vigor benih. Faktor yang mempengaruhi vigor, meliputi genetik, kematangan benih, lingkungan, ukuran benih, dan mikroorganisme (Yudono, 2006).

\section{Koefisien Vigor}

Hasil perhitungan koefisien vigor benih pala dapat dilihat pada Lampiran 5 . Berdasarkan hasil yang diperoleh yaitu 14.400 menunjukkan pada kualitas benih yang baik sehingga proses perkecambahan dapat terjadi walaupun pada keadaan lingkungan suboptimum. Bila benih mempunyai vigor lebih besar dari 30 merupakan benih yang memiliki kecepatan tumbuh yang lebih kuat (Sadjad, 1993). 
Pengujian vigor benih sangat diperlukan dalam informasi mutu benih.

Koefisien vigor menunjukan kualitas benih yang baik sehingga mempengaruhi proses perkecambahan menjadi lebih cepat terjadi. Hasil koefisien vigor yang diperoleh yaitu 14.400 menunjukan kualitas vigor yang tinggi. Benih dengan nilai vigor ini dapat tumbuh normal pada lingkungan suboptimum, karena benih yang bervigor tinggi, tingkat produksifitasnya juga sangat tinggi.

Utami (2011) mengatakan bahwa benih yang performannya bagus disebut benih bervigor tinggi, sedangkan sebaliknya adalah benih bervigor rendah. vigor benih termasuk salah satu sifat-sifat benih yang menentukan potensi untuk pemunculan kecambah yang cepat, serempak, dan normal pada kondisi lingkungan yang bervariasi.

\section{KESIMPULAN}

Berdasarkan penelitian yang telah dilakukan dan hasil yang diperoleh, maka dapat disimpulkan:

1. Hormon giberalin dapat mematahkan dormansi benih pala (Myristica fragrans), pada hari ke -14 HST

2. Konsentrasi hormon giberalin yang paling baik untuk mematahkan dormansi benih pala (Myristica fragrans) adalah $50 \mathrm{ppm}\left(\mathrm{G}_{2}\right)$.

\section{SARAN}

Untuk mematahkan dormansi benih pala dapat menggunakan giberalin $50 \mathrm{ppm}$. Perlu dilakukan penelitian lanjut dengan perlakuan kimia menggunakan $\mathrm{HCl}$ atau metode pematahan dormansi dengan skarifikasi.

\section{DAFTAR PUSKATA}

Agustrina, R. 2008. Perkecambahan dan Pertumbuhan Kecambah Leguminoceae dibawah Pengaruh Medan Magnet. Prosiding Seminar Hasil Penelitian dan Pengabdian kepada Masyarakat. Universitas Lampung, Bandarlampung. Arifin, Z., P. Yudono., dan Toekidjo. 2014. Pengaruh Konsentrasi $\mathrm{GA}_{3}$ Terhadap Pembungaan dan Kualitas Benih Cabai Merah Keriting (Capsicum annuum L). Jurnal Vegetalika, 1(4): 128-140.

Arijani. 2005. Biologi dan Konservasi Marga Myristica di Indonesia. Jurnal Biodiversitas, 6(2): 147-151.

Asra, R. 2014. Pengaruh Hormon Giberalin $\left(\mathrm{GA}_{3}\right)$ Terhadap Daya Kecambah dan Vigoritas (Calopogonium caeruleum). Jurnal Biospecies, 7(1): 29-33.

Belakbir, A., J.M. Ruiz. and L. Romero. 1998. Yield and Fruit Quality of Pepper (Capsicum Annuum L) in Response to Bioregulators. 33(1): 65-68.

Bukhari. 2013. Pengaruh Konsentrasi $\mathrm{KNO}_{3}$ dan Lama Perendaman Terhadap Viabilitas dan Vigor Benih Pepaya (Carica papaya L). [Skripsi]. Prodi Agroekoteknologi, Fakultas Pertanian, Universitas Teukur Umar Meulaboh, Aceh Barat.

Chaudhary, B.R., M.D. Sharma., S.M. Sakya., dan D.M. Gautam. 2006. Effec off Plant Growt, Yield and Quality of Chili (Casicum annuum L) at Ramput Chitwan. Journal Agric, 27: 65-68.

Dina, M. 2012. Respon Perkecambahan Benih Pinang (Areca catechu) Terhadap Berbagai Skariikasi dan Kosentrasi Asam Giberalat $\left(\mathrm{GA}_{3}\right)$. Jurnal online Agroekoteknologi, 1(1): 12

Erydhatirti, D.P. 2014. Aktifitas Antibakteri Minyak Biji Pala (Myristica fragrans Houtt.) Terenkapsulasi Pada Pure Jambu 
Biji Merah ( Psidium guajava L.). [Skripsi]. Departemen Ilmu dan Teknologi Pangan, IPB, Bogor.

ISTA. 2007. International Rules for Seed Testing: Edition 2006. The International Seed Testing Association. Bassersdorf. Switzerland.

Lesololo, M.K., J. Riry., dan E.A. Matatula. 2013. Pengujian Viabilitas dan Vigor Benih Beberapa Jenis Tanaman yang Beredar di Pasaran Kota Ambon. Jurnal Agrologia, 2(1): 1-9.

Mokodompit, T.M. 2005. Perkecambahan Benih Pala (myristica fragrans Hout) dengan Pemberian Giberalin dan Auksin. [Skripsi]. Fakultas MIPA UNSRAT, Manado.

Muhammad, S.S., E. Adelina., dan T. Budiarti. 2008. Pengaruh Skarifikasi dan Media Tumbuh terhadap Viabilitas Benih Dan Vigor Kecambah Aren. Jurnal Ilmu Pertanian Indonesia, 13(1): 7-12.

Murniati dan E. Zuhri. 2002. Peranan GiberaliTerhadap Perkecambahan Benih Kopi Robusta Tanpa Kulit. Jurnal Sagu, 1(1): 1-5.

Naning, Y., dan D.F. Djaman. 2015. Teknik PematahanDormansi untuk MempercepatPerkecambahan Benih Kourbaril (Hymenaea courbaril). Jurnal Balai Penelitian Teknologi Perbenihan Tanaman Hutan. 1(6): 1433-1437

Nurshanti, D.F. 2009. Zat Pengatur Tumbuh Asam Giberalin $\left(\mathrm{GA}_{3}\right)$ DAN Pengaruh Terhadap Perkecambahan Benih Palem Raja (Roystonea regia). Jurnal Agronobis. 1(2): 71-77

Oben, B.Afif., dan R. Melya. Pengaruh Perendaman Benih pada Berbagai Suhu Awal Air Terhadap Viabilitas Benih
Kayu Afrika (Maesopsis eminii). Jurnal Lestari, 2(1): 101-108.

Prawiranata, W., S. Harran dan Tjondronegoro. 1988. Dasar-dasar Fisiologi Tumbuhan. Fakultas Pertanian IPB, Bogor.

Priadi, D., dan N. Sumiasri. 2003. Pengaruh Lama Penyimpanan dan Zat Pengatur Tumbuh $\quad\left(\mathrm{GA}_{3}\right) \quad$ Terhadap Perkecambahan Biji Saga Telik (Adenanthera pavonina L.). Jurnal Ilmiah Pertanian, Universitas Islam Riau. 6(1): 53-56

Purnobasuki.H.2011.Perkecambahan.http//:s kp.unair.ac.id/repositori/Guru./Perkecam bahanHeryPurnobasuki_237.pdf

[Diakses 23 Mei 2011].

Putu, E.S.D., S. Samudin., dan Adrianton. 2015. Perkecambahan Benih Pala (Myristica fragrans Houtt) dengan Metode Skarifikasi dan Perendaman ZPT Alami. e-Journal Agrotekbis, 3(2): $158-167$

Ratna, D., H. Sutrino dan Nasirwan. 2013. Pemulihan Deteriorasi Biji Kedelai (Glycine Max L.) dengan Aplikasi Giberalin. Jurnal Penelitian Pertanian Terapan, 13(2): 116-122

Rismunandar. 1990. Budidaya dan Tataniaga Pala. Cetakan Kedua. Penebar Swadaya, Jakarta.

Rismunandar. 1992. Hormon Tanaman dan Ternak. Penebar Swadaya, Jakarta.

Sadjad, S., Muniarti. E., Ilyas. S. 1999. Parameter Pengujian Vigor Benih dari Komperatif ke Simulatif. Grasindo, Jakarta.

Sadjad, S., 1993. Dari Benih Kepada Benih. Rajawali Press, Jakarta.

Salisbury, F. B. dan Ross. C. W. 1992. Fisiologi Tumbuhan. ITB, Bandung. 
Sastramiharja, D. dan A. Siregar. 1997.

Fisiologi Tumbuhan. Jurusan Biologi ITB, Bandung.

Supardy., A. Enny, M. Usman 2016.

Pengaruh Lama Perendaman dan

Konsentrasi Giberalin $\left(\mathrm{GA}_{3}\right)$ Terhadap

Viabilitas Benih Kakao (Theobroma cacao L.) Jurnal Agrotekbis 2(3): 425431

Sutopo, L. 1993. Teknologi Biji. Fakultas Pertanian Universitas Brawijaya, Malang.

Sutopo, L, 2004. Teknologi Benih. Raja Grafindo Persada, Jakarta

Utami, E.P. 2013. Perlakuan Priming Benih untuk Mempertahankan Vigor Benih Kacang Panjang (Vigna unguiculata) Selama Penyimpanan. [Skripsi]. Departemen Agronomi dan Hortikultura, Institut Pertanian Bogor. Bogor.

Yuniarti, N., dan E. Reustaman. 2011. Teknik Pengemasan Benih Rekalsitran untuk Transportasi. Prosiding Seminar Hasil-Hasil Penelitian. Balai Penelitian Teknologi Pembenihan, Bogor.

Yudono, A., dan W.M. Purwanto. 2006. Kajian Aspek Fisiologi dan Biokimia Deteriorasi Benih Kedelai dalam Penyimpanan. Jurnal Ilmu Pertanian. 11(2): 76-87

Zahrotun, N.L.E.F., S. Dermawan., dan Respartijati. 2017. Uji Vigor dan Viabilitas Benih Dua Klon Karet (Hevea brasiliensis Muell Arg).Jurnal Produksi Tanaman 5(3): 484-492 